\title{
Organizational Citizenship Behavior and Corporate Social Responsibility: Evidence from Taiwan Listed Electronics Firms
}

\author{
Hsien-Ming Shih ${ }^{1}$, Bryan H. Chen ${ }^{1}$, Mei-Hua Chen ${ }^{1} \&$ Ching-Hsin Wang ${ }^{2}$ \\ ${ }^{1}$ Department of Finance, National Changhua University of Education, Changhua City, Taiwan \\ ${ }^{2}$ Department of Information Management, National Chin-Yi University of Technology, Taichung City, Taiwan \\ Correspondence: Ching-Hsin Wang, Department of Information Management, National Chin-Yi University of \\ Technology, Taichung City, Taiwan.
}

Received: December 25, 2021

Accepted: February 3, $2022 \quad$ Online Published: February 17, 2022

doi:10.5539/ijms.v14n1p18

URL: https://doi.org/10.5539/ijms.v14n1p18

\begin{abstract}
As enterprises expand, they have increasingly consumed social resources and influenced the society. The public has gradually become aware of this, and consequently, enterprises have begun to emphasize corporate social responsibility as a core business strategy. The interviewees/participants in the study were listed electronics companies in central Taiwan. Questionnaires were used in the study to collect data. A total of 211 valid questionnaires were collected and IBM SPSS 20 was used to analyze the data. The result of the study shows that interviewees participants doubt whether their companies fairly assess their performance or not; however, they consider that their companies take the responsibility of complying with the law and maximizing profits. As a result, medium or large enterprises, or listed electronics companies that intend to fulfill corporate social responsibility, should invite supervisors, senior employees, or female employees and those who do not typically participate in decision making or regular meetings (e.g., employees who work on production lines, or those who are not supervisors or do not work in marketing) to participate in meetings, and provide them training, or distribute manuals or send letters to them. This can enhance organizational citizens' identification with their company, motivate them to help their companies fulfill corporate social responsibility and thereby improve corporate image, enhance employees' commitment and awareness of organizational citizenship, and create an improved organizational climate.
\end{abstract}

Keywords: corporate social responsibility, economic responsibility, electronics firms, organizational citizenship behavior

\section{Introduction}

Fulfilling corporate social responsibility is crucial for business operation. According to Carroll (1979), corporate social responsibility has four dimensions: economic, legal, ethical, and charitable responsibilities. Carroll (1996) indicates that enterprises have economic, legal, and moral responsibilities. According to Griffin (2000), corporate social responsibility refers to enterprises' obligations to protect and improve their society. Most profit-seeking enterprises are concerned about the substantive effect of paying attention to corporate social responsibility. Vogel (2005) considers that companies should not only abide by the law but also take responsibilities because of strategic, defensive, or altruistic considerations. Kotler and Lee (2005) consider that fulfilling corporate social responsibility is typically recognized by the public, and that public recognition positively influences companies. Porter and Kramer (2006) indicate that fulfilling corporate social responsibility can create competitive advantages, and Brown (2008) explained that numerous enterprises consider corporate social responsibility a brand strategy and a competitive advantage. Therefore, if an enterprise can consider the interests of stakeholders, it can use its business strategy to maximize its profits. In addition, whether or not an enterprise is willing to fulfill corporate social responsibility, the public evaluates corporate performance based on its fulfillment of corporate social responsibility; accordingly, enterprises often develop their business strategies depending largely on the public's evaluation.

Wei and Zhuang (2009) indicate that corporate social responsibility has a wide scope, and that two types of corporate social responsibility exist: external and internal. "External" refers to an enterprise's corporate social responsibility for the public and consumers (e.g., environmental protection and participation in charitable activities), whereas "internal" refers to corporate governance, financial performance, legal compliance, and the 
protection and welfare of employees. Numerous researchers have explored the influence of corporate social responsibility on corporate externality and specific groups (e.g., employees or customers). When fulfilling corporate social responsibility, an enterprise should understand employees' views about the enterprise's performance. Turker (2009) indicates that companies that fulfill corporate social responsibility positively influence employees' organizational commitment.

The concept of Organizational Citizenship Behavior (OCB) was proposed by Katz (1964) in role theory, which holds that employees are typically required to complete their organizational tasks and to present in-role behavior, but in addition, they must engage in extra-role behavior (i.e., spontaneity, cooperation, and innovation) to achieve their organizations' goals. Organ (1988) and Konovsky and Pugh (1994) indicate that organizational rewards are irrelevant to employees' organizational citizenship behavior (OCB); OCB is typically spontaneous and not required by the employers. Organ (1990) proposes that OCB can benefit organizations and is not defined according to employees' roles or contracts. Organ (1988) also indicates that no organization is perfect and that an organization cannot effectively achieve its goals by depending solely on employees' in-role behavior. Lin (1992) expresses that organizations should rely on employees' extra-role behavior to achieve their goals. Researchers vary in their understandings of OCB. Smith, Organ and Near (1983) consider OCB to have two dimensions (altruism and general compliance behavior), whereas Organ (1988) considers it to have five (altruism, courtesy, sportsmanship, conscientiousness, and civic virtue) and Graham (1991) considers it to have three (compliance, loyalty, and participation). Organ et al. (2006) explain that employees make their own decisions about whether to adopt OCB; even if they choose not to, they do not worry about being punished by their employers. Bateman and Organ (1983) and Smith et al. (1983) indicate that OCB is a crucial research topic for researchers in the organizational behavior field. Numerous researchers have explored the definition of OCB and paid attention to the relationship between variables.

Valentine and Fleischman (2008) and Kunda, Ataman and Kartaltepe Behram (2019) indicate that corporate social responsibility influences employee job satisfaction. By encouraging $\mathrm{OCB}$, an organization can enhance performance and create a harmonious atmosphere. The questions are how OCB can be encouraged, whether employees commit themselves to their organizations if their organizations fulfill corporate social responsibility, and whether employees' positive feelings are correlated with OCB and organizational performance.

Corporate social responsibility means that an enterprise undertakes activities to attain social values and improve society. In a righteous and sympathetic environment, employees engage in $\mathrm{OCB}$, by, for example, identifying with their organizations, providing useful suggestions, protecting resources, and avoiding disputes with their colleagues. The present study considers that a company that emphasizes corporate social responsibility takes responsibility for its employees (e.g., by stressing environmental safety and employee welfare); accordingly, the company creates an altruistic atmosphere and a satisfying workplace, thereby encouraging its employees to engage in OCB. However, questions arise whether employees unconditionally agree with their organizations' behavior regarding corporate social responsibility and whether their own attitudes toward corporate social responsibility influence their OCB.

In the present study, we explore employees' attitudes toward corporate social responsibility and the relationship between their attitudes and OCB. The research questions for this study are as follows:

1) What are employees' attitudes toward corporate social responsibility?

2) What are employees' attitudes toward OCB?

3) Do differences in the attitude toward corporate social responsibility and OCB exist between employees of varying backgrounds?

4) Is the attitude toward corporate social responsibility related to the attitude toward OCB?

In the present study, we explore employees' attitudes toward corporate social responsibility and the relationship between their attitudes and OCB.

\section{Materials}

\subsection{Corporate Social Responsibility}

Corporate social responsibility has become a major issue receiving substantial attention. Given that enterprises are held accountable to stakeholders, society, and the public, corporate social responsibility is a crucial consideration. Bowen (1953), the father of corporate social responsibility, defines corporate social responsibility as "the obligations of businessmen to pursue those policies, to make those decisions, or to follow those lines of action which are desirable in terms of the objectives and values of our society". Carroll (1979) considers that 
business operators who intend to take on corporate social responsibility must understand its fundamental definition, as well as the problems related to the existence of social responsibility and those reflected in normative business philosophy. Singh et al. (2008) considers that corporate social responsibility had three dimensions: commercial, moral, and social. As Gao (2008) indicates, corporate social responsibility means that enterprises that abide by ethical and moral principles must protect the interests of stakeholders, shareholders, and consumers while valuing the human rights of employees, supplier management, environmental protection, community participation, and the disclosure of financial information. In addition, corporate social responsibility includes economic, legal, moral, and charitable responsibilities. These are detailed as follows: (1) Economic responsibility: A business organization is a basic economic unit; an enterprise has a responsibility to provide products and services and to generate profits; (2) Legal responsibility: Enterprises are producers and their production activities must follow all relevant regulations; (3) Moral responsibility: The public expects that enterprises should take responsibilities beyond complying with the law and regulations; (4) Charitable responsibility: In spite of no rule defined in the law and ethics, enterprises should be willing to participate in charitable activities, to meet public expectations, and improve life in wider society.

\subsection{Organizational Citizenship Behavior}

According to Bateman and Organ (1983), OCB has the following dimensions: helping new employees become familiar with working conditions, providing suggestions, complying with company regulations, tolerating unpleasant working conditions, and avoiding creating problems for the company or colleagues. Organ (1988) proposes five types of OCB: altruism, conscientiousness, sportsmanship, courtesy, and civic virtue. Altruism means that organization members are willing to spend time unconditionally helping their colleagues solve problems at work. Conscientiousness means that organization members not only fulfill their duties but also actively endeavor to achieve organizational goals. Sportsmanship means that organization members hold a positive attitude despite their disappointments at work, including the internal imperfections of their organizations. Courtesy means that organization members actively inform other members of work-related information to avoid problems. Civic virtue means that organization members take the initiative to understand organizational operations, participate in various organizational activities, provide suggestions, and improve service quality.

Organ (1990) indicates that OCB is meaningful behavior not inherent in a formal role or limited by contracts, but rather arising from unofficial dedication. People typically do not consider punishment or incentives when deciding whether to engage in OCB. Williams and Anderson (1992) propose the concepts of organizational citizenship behavior-individual (OCBI) and organizational citizenship behavior-organization (OCBO). OCBI is a type of OCB useful directly for individuals and indirectly for organizations, whereas OCBO is a type of OCB useful directly for organizations.

Konovsky and Pugh (1994) consider OCB a type of behavior that employees engage in not because it is within their duties or salary structure, but at their discretion. From the perspective of a psychological contract, Robinson and Morrison (1995) indicate that OCB goes beyond employment contracts and beyond formal duties; whether to engage in OCB depends on particular situations, and no formal rewards are granted for it.

Coleman and Borman propose three types of OCB: individual-oriented, organization-oriented, and task-oriented. Individual-oriented OCB means that employees take greater initiative than expected to support their colleagues, cooperate with them, and achieve organizational goals. Organization-oriented OCB means that employees dedicate themselves to their organization, complying with its rules and protecting its interests. Task-oriented OCB means that employees make an extra effort to enhance their job performance; for example, employees endeavor to provide quality service to consumers. In the aforementioned studies, OCB is described through the characteristics and meanings of behavior. Lin (2005) described OCB on the basis of who is targeted by the behavior and explains that OCB involves employees taking initiative to help their supervisors present leadership behavior. In summary, OCB involves organization members dedicating themselves to help other members of their organization despite the lack of formal rewards, making a contribution that enhances the overall effectiveness of their organization.

\subsection{The Relationship Between Corporate Social Responsibility and Organizational Citizenship Behavior}

The present study elucidates the relationship between corporate social responsibility and OCB from a practical perspective. This perspective considers that individuals learn from observation, experience, identification, imitation, and most of all by interacting with their environment. Farh et al. (1997) indicate that employees who fit in with their organizational culture commit to their organizations and achieve enhanced job satisfaction. Therefore, integrating corporate social responsibility into organizational culture, helping employees to recognize its importance and associate it with their values, can enhance their job satisfaction and strengthen their 
commitment to their organization. According to Xie and Xu (2009) corporate social responsibility means that enterprises take responsibility for their employees, shareholders, investors, consumers, supply chain, community, and government, and recompense the society from which they obtain resources. In this manner, enterprises can enhance their corporate image and create a satisfying workplace with a caring and altruistic atmosphere. As Zhang (2010) claims, enterprises can persuade their employees that they are not only concerned about their own interests if they exhibit making social contributions, rewarding consumers, and caring for their own employees. Accordingly, if employees can recognize the organization's values in the resulting altruistic atmosphere, they can understand the meaning of corporate social responsibility and engage in positive behavior. Therefore, in the present study, we hypothesize that corporate social responsibility positively influences OCB. Louise Tourigny, Jian Han, Vishwanath V. Baba and Polly Pan (2019) propose that the ethical stance of supervisors influences subordinates' perceptions of corporate social responsibility (CSR) which in turn influences subordinates' trust in the organization resulting in their taking increased personal social responsibility and engagement in organizational citizenship behaviors (OCB) oriented toward both the organization and other individuals

Zhou, Chen and $\mathrm{Wu}$ (2012) and Kunda, Ataman and Kartaltepe Behram (2019) find that when employees discover new meaning in their jobs and identify with their organization, they feel that they are truly part of it and closely connect with their workplace. When employees recognize the relevance of corporate social responsibility and that their values are consistent with organizational values, they are motivated to engage in OCB. If an enterprise can contribute to society and meet societal requirements in many aspects, its employees support each other, are proud of the enterprise, and their performance improves.

\section{H3: There is no significant correlation between corporate social responsibility and organizational citizenship behavior.}

\section{Methods}

The interviewees/participants in the study were listed electronics companies in central Taiwan. Questionnaires were used in the study to collect data. A total of 211 valid questionnaires were collected, and IBM SPSS 20 was used to analyze the dThe research mainly studies whether corporate employees' implementation of corporate social responsibility has an impact on organizational citizenship behavior. Based on the above literature discussion, the research framework of this study is established.

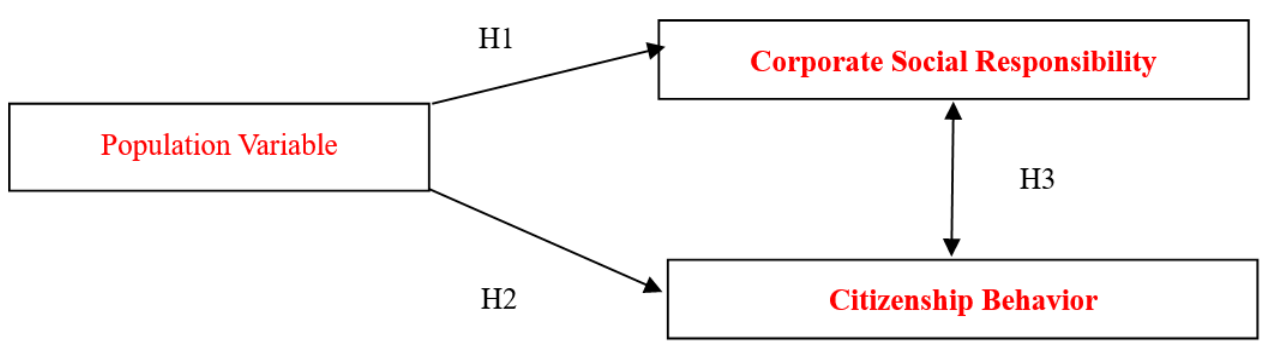

Figure 1. Research architecture diagram

\subsection{Labeling of Hypothesis}

Corporate social responsibility is the pursuit of all activities that conform to social values and satisfy the society. Employees are in an environment that contributes to social justice, sympathy and empathy, which will have an impact on the individual employee and thus identify and maintain the organizational environment, or care about and put forward suggestions that are beneficial to the organization, Performance of organizational citizenship behaviors such as reducing conflicts among colleagues and protecting resources within the organization. For example, scholars Zhou CongYou and Wu JiaLing (2010) proposed in their research that corporate social responsibility has a positive and significant impact on organizational citizenship behavior. Therefore, this study will discuss the following research hypotheses based on the above inference theory. The main questions of this study are as follows:

H1: There is no significant difference in CSR among different demographic variables.

$\mathrm{H} 2$ : There is no significant difference between different demographic variables and organizational citizenship behavior. 
H3: There is no significant correlation between corporate social responsibility and organizational citizenship behavior.

\subsection{Research Instruments}

Following previous studies, we first designed questions for various assessment dimensions and then invited scholars and experts to revise the questions for a pilot study. The validity of the questionnaire draft was examined once more by experts and the questionnaire draft modified before the pilot study was conducted. Following the pilot study, no questions were removed or added to the questionnaire. The values of Cronbach's $\alpha$ were 0.944 for the questionnaire, 0.945 for the dimension of corporate social responsibility, and 0.874 for organizational citizens' identification with corporate social responsibility $(>0.7)$, indicating that this questionnaire possesses excellent reliability and high consistency.

The questionnaire comprised three parts: the corporate social responsibility scale, the OCB scale, and demographic information. The corporate social responsibility scale was designed according to previous reports on global environmental, economic, and social sustainability, as well as previous questionnaires developed by Mowday et al. (1979), Bateman and Organ (1983), Smith et al. (1983). It covered the four dimensions of corporate social responsibility (economic, environmental, ethical, and legal) and consisted of 24 questions. The OCB scale was designed according to Farh et al. (1997). This scale covered two dimensions (identifying with corporate social responsibility and providing support to colleagues) and comprised 8 questions. The demographic information included gender, educational attainment, age, marital status, department, current position, and number of years employed in the current organization. In the first and second parts, a 5-point Likert scale was adopted, and the third part used a category scale. The data collected were used for empirical analysis.

\subsection{Participants}

To analyze the influence of corporate social responsibility on OCB, we recruited employees from listed electronics companies in central Taiwan. Since collecting questionnaires from a business organization was challenging, we adopted a convenience sampling method. We first contacted company staff by telephone to obtain their permission to distribute questionnaires to their employees; subsequently, we requested that managers distribute the questionnaires. After employees filled them out, the questionnaires were sealed and collected by a representative. To maintain the validity of the questionnaire, only full-time employees were recruited. Overall, 300 questionnaires were distributed, and 256 questionnaires returned; after 45 incomplete questionnaires were discarded, a total of 211 valid questionnaires remained for data analysis. Thus, the return rate was $85.33 \%$ and the valid sample was $70.33 \%$.

\section{Discussion}

\subsection{Descriptive Statistics for Demographic Information}

Table 1 presents descriptive statistics for participants' demographic information. Most participants were men (55.9\%). By age, the largest proportion of participants were 31 to 40 years old (41.2\%). Most participants were not supervisors $(88.1 \%)$. Married participants accounted for $53.1 \%$ of the sample (46.9\% were single), and $81.9 \%$ had a bachelor's or master's degree. The largest proportion of participants had been employed by their current organizations for 6 to 10 years $(38.4 \%)$, followed by those who were employed for 0 to 5 years (37.4\%); together, these groups accounted for $75.8 \%$ of the total employees. 
Table 1. Descriptive statistics for demographic information

\begin{tabular}{llll}
\hline Variable & & Frequency & Percentage \\
\hline Gender & Men & 118 & 55.9 \\
Educational attainment & Women & 93 & 44.1 \\
& Graduate school & 52 & 24.6 \\
& University & 121 & 57.3 \\
& Junior college & 33 & 15.6 \\
Age & Senior or vocational high school or below & 5 & 2.4 \\
& 30 years or below & 63 & 29.9 \\
& 31-40 years & 87 & 41.2 \\
Marital status & 41-50 years & 50 & 23.7 \\
\multirow{5}{*}{ Department } & 51 years or more & 11 & 5.2 \\
& Single & 99 & 46.9 \\
& Married & 112 & 53.1 \\
& Marketing & 28 & 13.3 \\
Position & Management & 46 & 21.8 \\
& Research and development & 6 & 2.8 \\
Years of employment & Others & 131 & 62.1 \\
& Non-supervisor & 186 & 88.2 \\
& Supervisor & 25 & 11.8 \\
& 0-5 years & 79 & 37.4 \\
& 6-10 years & 81 & 38.4 \\
& 11-15 years & 28 & 13.3 \\
& 16 years or more & 23 & 10.9 \\
\hline
\end{tabular}

\subsection{Descriptive Statistics}

Table 2 presents descriptive statistics for various variables. In the corporate social responsibility dimension, the employees identified with legal responsibility to the highest degree, followed by economic responsibility. In the OCB dimension, employees scored highest on providing support to colleagues. Regarding individual questions: In the corporate social responsibility dimension, the employees identified the least with evaluation fairness $(\mathrm{M}=$ $3.79, \mathrm{SD}=0.85)$ and the most with complying with the law $(\mathrm{M}=4.26, \mathrm{SD}=0.70)$. In the $\mathrm{OCB}$ dimension, employees scored highest on actively helping new colleagues $(\mathrm{M}=4.12, \mathrm{SD}=0.63)$ and lowest on companies' participation in activities related to corporate social responsibility $(\mathrm{M}=3.82, \mathrm{SD}=0.80)$. 
Table 2. Descriptive statistics

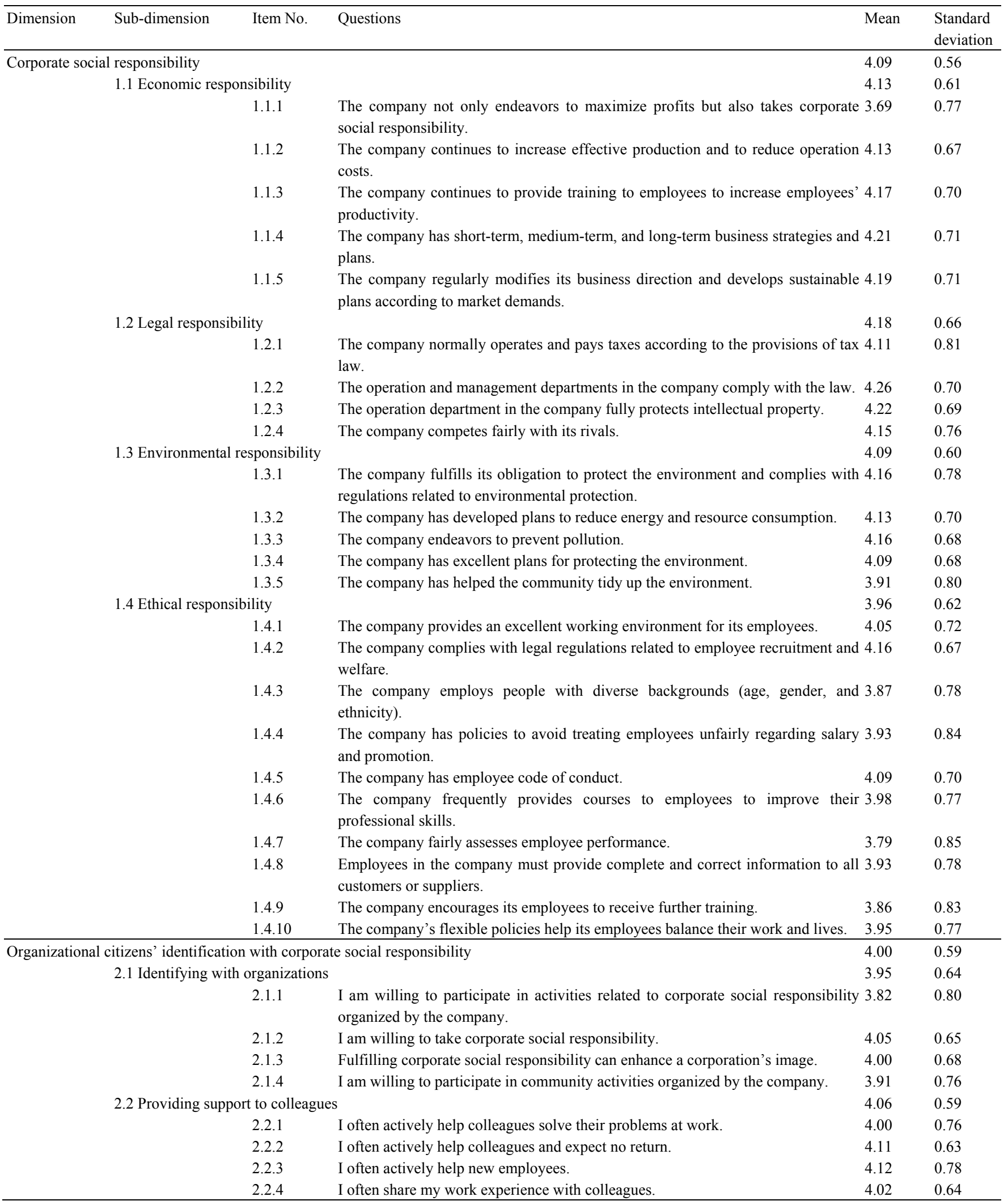

\subsection{T-Tests for Gender, Marital Status, and Position (Table 3)}

For the corporate social responsibility and OCB dimensions, the scores of women, married employees, and supervisors were significantly higher than those of men, single employees, and nonsupervisory, respectively. 
Table 3. T-test results

\begin{tabular}{|c|c|c|c|c|c|c|}
\hline Variable & Gender & Frequency & Mean & Standard deviation & T value & $P$ value \\
\hline \multirow[t]{2}{*}{ Corporate social responsibility } & Men & 118 & 3.97 & .555 & -3.644 & .000 \\
\hline & Women & 93 & 4.25 & .535 & & \\
\hline \multirow[t]{2}{*}{ Dimension A } & Men & 118 & 3.96 & .633 & -4.952 & .000 \\
\hline & Women & 93 & 4.36 & .508 & & \\
\hline \multirow[t]{2}{*}{ Dimension B } & Men & 118 & 4.04 & .643 & -3.637 & .000 \\
\hline & Women & 93 & 4.37 & .638 & & \\
\hline \multirow[t]{2}{*}{ Dimension C } & Men & 118 & 4.00 & .594 & -2.472 & .014 \\
\hline & Women & 93 & 4.20 & .599 & & \\
\hline \multirow[t]{2}{*}{ Dimension D } & Men & 118 & 3.88 & .570 & -2.087 & .038 \\
\hline & Women & 93 & 4.06 & .667 & & \\
\hline \multirow[t]{2}{*}{$\mathrm{OCB}$} & Men & 118 & 3.91 & .549 & -2.758 & .006 \\
\hline & Women & 93 & 4.13 & .618 & & \\
\hline \multirow[t]{2}{*}{ Dimension E } & Men & 118 & 3.87 & .568 & -1.919 & .056 \\
\hline & Women & 93 & 4.04 & .716 & & \\
\hline \multirow[t]{2}{*}{ Dimension F } & Men & 118 & 3.94 & .588 & -3.180 & .002 \\
\hline & Women & 93 & 4.22 & .663 & & \\
\hline Variable & Marital status & Frequency & Mean & Standard deviation & Tvalue & $P$ value \\
\hline \multirow[t]{2}{*}{ Corporate social responsibility } & Single & 99 & 3.95 & .549 & -3.447 & .001 \\
\hline & Married & 112 & 4.21 & .547 & & \\
\hline \multirow[t]{2}{*}{ Dimension A } & Single & 99 & 3.98 & .668 & -3.615 & .000 \\
\hline & Married & 112 & 4.27 & .525 & & \\
\hline \multirow{2}{*}{ Dimension B } & Single & 99 & 4.04 & .636 & -2.995 & .003 \\
\hline & Married & 112 & 4.31 & .657 & & \\
\hline \multirow[t]{2}{*}{ Dimension C } & Single & 99 & 3.97 & .598 & -2.672 & .008 \\
\hline & Married & 112 & 4.19 & .592 & & \\
\hline \multirow[t]{2}{*}{ Dimension D } & Single & 99 & 3.82 & .572 & -3.094 & .002 \\
\hline & Married & 112 & 4.08 & .636 & & \\
\hline \multirow[t]{2}{*}{$\mathrm{OCB}$} & Single & 99 & 3.81 & .565 & -4.587 & .000 \\
\hline & Married & 112 & 4.17 & .561 & & \\
\hline \multirow{2}{*}{ Dimension E } & Single & 99 & 3.76 & .604 & -4.093 & .000 \\
\hline & Married & 112 & 4.11 & .631 & & \\
\hline \multirow[t]{2}{*}{ Dimension F } & Single & 99 & 3.87 & .619 & -4.316 & .000 \\
\hline & Married & 112 & 4.23 & .603 & & \\
\hline Variable & Position & Frequency & Mean & Standard deviation & T value & $P$ value \\
\hline \multirow[t]{2}{*}{ Corporate social responsibility } & Non-supervisor & 186 & 4.06 & .542 & -2.641 & .009 \\
\hline & Supervisor & 25 & 4.37 & .646 & & \\
\hline \multirow[t]{2}{*}{ Dimension A } & Non-supervisor & 186 & 4.08 & .607 & -3.743 & .000 \\
\hline & Supervisor & 25 & 4.55 & .494 & & \\
\hline \multirow[t]{2}{*}{ Dimension B } & Non-supervisor & 186 & 4.16 & .641 & -1.746 & .082 \\
\hline & Supervisor & 25 & 4.40 & .764 & & \\
\hline \multirow[t]{2}{*}{ Dimension C } & Non-supervisor & 186 & 4.06 & .579 & -2.045 & .042 \\
\hline & Supervisor & 25 & 4.32 & .733 & & \\
\hline Dimension D & Non-supervisor & 186 & 3.93 & .590 & -2.048 & .042 \\
\hline & Supervisor & 25 & 4.20 & .779 & & \\
\hline $\mathrm{OCB}$ & Non-supervisor & 186 & 3.96 & .580 & -3.198 & .002 \\
\hline & Supervisor & 25 & 4.35 & .553 & & \\
\hline Dimension E & Non-supervisor & 186 & 3.90 & .631 & -2.562 & .011 \\
\hline & Supervisor & 25 & 4.25 & .645 & & \\
\hline Dimension F & Non-supervisor & 186 & 4.01 & .631 & -3.332 & .001 \\
\hline & Supervisor & 25 & 4.45 & .540 & & \\
\hline
\end{tabular}


4.4 One-Way Analysis of Variance (ANOVA) for Age, Department, the Number of Years Employed, and Educational Attainment (Table 4)

Table 4. ANOVA results

\begin{tabular}{|c|c|c|c|c|c|c|c|c|c|c|}
\hline Item & $\begin{array}{l}\text { Degree of } \\
\text { freedom }\end{array}$ & $\mathrm{F}$ & $\mathrm{P}$ & 1 & 2 & 3 & 4 & \multicolumn{3}{|c|}{ Post hoc tests } \\
\hline \multicolumn{11}{|l|}{ Educational attainment } \\
\hline Dimension A & 3 & 1.424 & .237 & 4.14 & 4.08 & 4.33 & 4.04 & $3>1$ & $1>2$ & $2>4$ \\
\hline Dimension B & 3 & 1.871 & .136 & 4.15 & 4.15 & 4.41 & 3.85 & $3>1=2$ & $1=2>4$ & \\
\hline Dimension $\mathrm{C}$ & 3 & 1.675 & .174 & 4.09 & 4.03 & 4.30 & 4.12 & $3>4$ & $4>1$ & $1>2$ \\
\hline Dimension D & 3 & 1.522 & .210 & 4.01 & 3.90 & 4.14 & 3.84 & $3>1$ & $1>2$ & $2>4$ \\
\hline Corporate social responsibility & 3 & 1.849 & .139 & 4.10 & 4.04 & 4.29 & 3.96 & $3>1$ & $1>2$ & $2>4$ \\
\hline Dimension E & 3 & 1.516 & .211 & 3.92 & 3.90 & 4.16 & 3.80 & $3>1$ & $1>2$ & $2>4$ \\
\hline Dimension F & 3 & 1.118 & .343 & 4.05 & 4.03 & 4.23 & 3.85 & $3>1$ & $1>2$ & $2>4$ \\
\hline $\mathrm{OCB}$ & 3 & 1.529 & .208 & 3.99 & 3.97 & 4.20 & 3.83 & $3>1$ & $1>2$ & $2>4$ \\
\hline \multicolumn{11}{|l|}{ Age } \\
\hline Dimension A & 3 & 21.767 & .000 & 3.71 & 4.21 & 4.50 & 4.35 & $3>4$ & $4>2$ & $2>1$ \\
\hline Dimension B & 3 & 15.514 & .000 & 3.80 & 4.23 & 4.55 & 4.43 & $3>4$ & $4>2$ & $2>1$ \\
\hline Dimension $\mathrm{C}$ & 3 & 15.462 & .000 & 3.74 & 4.12 & 4.43 & 4.33 & $3>4$ & $4>2$ & $2>1$ \\
\hline Dimension D & 3 & 12.303 & .000 & 3.62 & 4.02 & 4.20 & 4.33 & $4>3$ & $3>2$ & $2>1$ \\
\hline Corporate social responsibility & 3 & 20.491 & .000 & 3.72 & 4.14 & 4.42 & 4.36 & $3>4$ & $4>2$ & $2>1$ \\
\hline Dimension E & 3 & 12.669 & .000 & 3.61 & 3.98 & 4.21 & 4.43 & $4>3$ & $3>2$ & $2>1$ \\
\hline Dimension F & 3 & 10.813 & .000 & 3.73 & 4.11 & 4.32 & 4.41 & $3>4$ & $4>2$ & $2>1$ \\
\hline $\mathrm{OCB}$ & 3 & 14.104 & .000 & 3.67 & 4.04 & 4.26 & 4.42 & $4>3$ & $3>2$ & $2>1$ \\
\hline \multicolumn{11}{|l|}{ Department } \\
\hline Dimension A & 3 & 10.354 & .000 & 4.34 & 4.47 & 4.27 & 3.96 & $2>1$ & $1>3$ & $3>4$ \\
\hline Dimension B & 3 & 11.892 & .000 & 4.44 & 4.56 & 4.38 & 3.99 & $2>1$ & $1>3$ & $3>4$ \\
\hline Dimension C & 3 & 10.405 & .000 & 4.31 & 4.43 & 4.07 & 3.93 & $2>1$ & $1>3$ & $3>4$ \\
\hline Dimension D & 3 & 7.754 & .000 & 4.08 & 4.30 & 3.88 & 3.82 & $2>1$ & $1>3$ & $3>4$ \\
\hline Corporate social responsibility & 3 & 12.613 & .000 & 4.29 & 4.44 & 4.15 & 3.93 & $2>1$ & $1>3$ & $3>4$ \\
\hline Dimension E & 3 & 16.478 & .000 & 4.25 & 4.32 & 4.42 & 3.73 & $3>2$ & $2>1$ & $1>4$ \\
\hline Dimension F & 3 & 24.938 & .000 & 4.29 & 4.58 & 4.38 & 3.81 & $2>3$ & $3>1$ & $1>4$ \\
\hline $\mathrm{OCB}$ & 3 & 24.717 & .000 & 4.27 & 4.45 & 4.40 & 3.77 & $2>3$ & $3>1$ & $1>4$ \\
\hline \multicolumn{11}{|c|}{ The number of employment years } \\
\hline Dimension A & 3 & 6.616 & .000 & 4.06 & 4.00 & 4.44 & 4.47 & $4>3$ & $3>1$ & $1>2$ \\
\hline Dimension B & 3 & 4.326 & .006 & 4.12 & 4.07 & 4.46 & 4.48 & $4>3$ & $3>1$ & $1>2$ \\
\hline Dimension $\mathrm{C}$ & 3 & 6.141 & .001 & 4.01 & 3.98 & 4.36 & 4.43 & $4>3$ & $3>1$ & $1>2$ \\
\hline Dimension D & 3 & 4.087 & .008 & 3.90 & 3.88 & 4.04 & 4.35 & $4>3$ & $3>1$ & $1>2$ \\
\hline Corporate social responsibility & 3 & 6.205 & .000 & 4.02 & 3.98 & 4.32 & 4.43 & $4>3$ & $3>1$ & $1>2$ \\
\hline Dimension E & 3 & 5.925 & .001 & 3.81 & 3.88 & 4.17 & 4.35 & $4>3$ & $3>2$ & $2>1$ \\
\hline Dimension F & 3 & 5.490 & .001 & 3.93 & 4.00 & 4.41 & 4.29 & $3>4$ & $4>2$ & $2>1$ \\
\hline $\mathrm{OCB}$ & 3 & 6.480 & .000 & 3.87 & 3.94 & 4.29 & 4.32 & $4>3$ & $3>2$ & $2>1$ \\
\hline
\end{tabular}


Table 5. Correlation analysis

\begin{tabular}{|c|c|c|c|c|c|c|c|c|c|}
\hline & & $\begin{array}{l}\text { Dimension } \\
\text { A }\end{array}$ & $\begin{array}{l}\text { Dimension } \\
\mathrm{B}\end{array}$ & $\begin{array}{l}\text { Dimension } \\
\mathrm{C}\end{array}$ & $\begin{array}{l}\text { Dimension } \\
\mathrm{D}\end{array}$ & $\begin{array}{l}\text { Corporate social } \\
\text { responsibility }\end{array}$ & $\begin{array}{l}\text { Dimension } \\
\text { E }\end{array}$ & $\begin{array}{l}\text { Dimension } \\
\mathrm{F}\end{array}$ & $\begin{array}{l}\mathrm{OCB} \\
\text { dimension }\end{array}$ \\
\hline \multirow[t]{2}{*}{ Dimension A } & Pearson correlation & 1 & $.825 * *$ & $.714^{* *}$ & $.644^{* *}$ & $.883^{* *}$ & $.509^{* *}$ & $.574^{* *}$ & $.586^{* *}$ \\
\hline & $\begin{array}{l}\text { \& significance } \\
\text { (two-tailed) }\end{array}$ & & .000 & .000 & .000 & .000 & .000 & .000 & .000 \\
\hline \multirow[t]{2}{*}{ Dimension B } & Pearson correlation & & 1 & $.821^{* *}$ & $.701^{* *}$ & $.931^{* *}$ & $.560^{* *}$ & $.575^{* *}$ & $.614^{* *}$ \\
\hline & $\begin{array}{l}\& \text { significance } \\
\text { (two-tailed) }\end{array}$ & & & .000 & .000 & .000 & .000 & .000 & .000 \\
\hline \multirow[t]{2}{*}{ Dimension C } & $\begin{array}{l}\text { Pearson correlation } \\
\&\end{array}$ & & & 1 & $.792^{* *}$ & $.922^{* *}$ & $.615^{* *}$ & $.554^{* *}$ & $.634^{* *}$ \\
\hline & $\begin{array}{l}\text { significance } \\
\text { (two-tailed) }\end{array}$ & & & & .000 & .000 & .000 & .000 & .000 \\
\hline \multirow[t]{2}{*}{ Dimension D } & $\begin{array}{l}\text { Pearson correlation } \\
\&\end{array}$ & & & & 1 & $.869^{* *}$ & $.672^{* *}$ & $.605^{* *}$ & $.692^{* *}$ \\
\hline & $\begin{array}{l}\text { significance } \\
\text { (two-tailed) }\end{array}$ & & & & & .000 & .000 & .000 & .000 \\
\hline $\begin{array}{l}\text { Corporate } \\
\text { social }\end{array}$ & $\begin{array}{l}\text { Pearson correlation } \\
\&\end{array}$ & & & & & 1 & $.653^{* *}$ & $.640^{* *}$ & $.700^{* *}$ \\
\hline responsibility & $\begin{array}{l}\text { significance } \\
\text { (two-tailed) }\end{array}$ & & & & & & .000 & .000 & .000 \\
\hline Dimension E & $\begin{array}{l}\text { Pearson correlation } \\
\& \text { significance } \\
\text { (two-tailed) }\end{array}$ & & & & & & 1 & $\begin{array}{l}.705^{* *} \\
.000\end{array}$ & $\begin{array}{l}.924^{* *} \\
.000\end{array}$ \\
\hline Dimension F & $\begin{array}{l}\text { Pearson correlation } \\
\& \\
\text { significance } \\
\text { (two-tailed) }\end{array}$ & & & & & & & 1 & $\begin{array}{l}.923^{* *} \\
.000\end{array}$ \\
\hline OCB & $\begin{array}{l}\text { Pearson correlation } \\
\& \\
\text { significance } \\
\text { (two-tailed) }\end{array}$ & & & & & & & & 1 \\
\hline
\end{tabular}

Note. The symbol “**” indicates that the significance level is 0.01 for a two-tailed test and a correlation coefficient is significant.

\subsection{Correlation Analysis (Table 5)}

These results show a significant difference in the corporate social responsibility dimension between men and women; in addition, men significantly differed from women in the following sub-dimensions: economic, legal, environmental, and ethical responsibilities. Compared with men, women identified with corporate social responsibility to a greater degree, with higher scores than men on the following questions: "the company has fulfilled its obligation to protect the environment," "the company provides an excellent working environment for its employees," "the company employs people with various backgrounds," "the company has employee code of conduct," "the company provides complete and correct information to customers."

The scores of married employees concerning the economic responsibility sub-dimension of corporate social responsibility were significantly higher than those of single employees. This was also the case for certain questions in the sub-dimensions of legal responsibility ("The company operates normally and pays taxes according to the provisions of tax law" and "the operation and management departments comply with the law"), environmental responsibility ("The company fulfills its obligation to protect the environment and has complied with regulations related to environmental protection"), ethical responsibility ("The company employs people with diverse backgrounds"), and in the OCB dimension ("I often actively help new employees").

The scores of employees aged 31 or above were significantly higher than those of employees aged 30 or below regarding the following: the entire economic responsibility sub-dimension, and these questions in the sub-dimensions of legal responsibility ("The company operates normally and pays taxes according to the provisions of tax law," and "The operation department in the company fully protects intellectual property"); environmental responsibility ("The company fulfills its obligation to protect the environment and has complied with regulations related to environmental protection" and "The company has helped the community tidy up the environment"); ethical responsibility ("The company provides an excellent working environment for its employees," "The company complies with legal regulations related to employee recruitment and welfare," "The 
company employs people with various backgrounds," "The company has employee code of conduct," "Employees in the company provide complete and correct information to all customers or suppliers," and "The company encourages its employees to receive further training"); identifying with organizations ("I am willing to participate in corporate social responsibility-related activities organized by the company," and "Fulfilling corporate social responsibility can enhance a corporation's image"); providing support to colleagues ("I often help colleagues solve their problems at work"), in addition to the corporate social responsibility and OCB dimensions. In addition, the scores of employees aged 41 to 50 years were significantly higher than those of employees aged 31 to 40 years for the following questions: "The company continues to maximize profits" and "The company continues to increase effective production and to reduce operation costs" in the economic responsibility sub-dimension; "The company operates normally and pays taxes according to the provisions of tax law," "The operation and management departments comply with the law," and "The operation department fully protects intellectual property" in the legal responsibility sub-dimension; and "The company has endeavored to prevent pollution" in the environmental responsibility sub-dimension. The scores of employees aged 41 to 50 years were also significantly higher than those of employees aged 31 to 40 years for the sub-dimensions of economic, legal, and environmental responsibility. The scores of employees aged 41 to 50 years were significantly higher than those of employees aged 30 or below for the following questions: "The company has developed plans to reduce energy and resource consumption" and "The company endeavors to prevent pollution" in the environmental responsibility sub-dimension; "The company has policies for avoiding unfairly treating employees regarding salary and promotion" in the ethical responsibility sub-dimension; and "I often actively help colleagues and expect no return" in the providing support to colleagues sub-dimension. The scores of employees aged 31 to 50 years were significantly higher than those of employees aged 30 years or below for the following questions: "The company competes fairly with its rivals" in the legal responsibility sub-dimension; "The company has excellent plans for protecting the environment" in the environmental responsibility sub-dimension; "The company's flexible policies help its employees balance their work and lives" in the ethical responsibility sub-dimension; and "I often actively help new employees" in the providing support to colleagues sub-dimension. The scores of employees aged 41 years or above were significantly higher than those of employees aged 30 years or below for "The company frequently provides courses to employees to improve their professional skills" in the ethical responsibility sub-dimension, as well as "I am willing to take corporate social responsibility" and "I am willing to participate in community activities organized by the company" in the identifying with organizations sub-dimension.

The scores of supervisors were significantly higher than those of non-supervisors for the sub-dimension of ethical responsibility as well as the following questions in that of environmental responsibility: "The company has fulfilled its obligation to protect the environment and has complied with regulations related to environmental protection," "The company has endeavored to prevent pollution," "The company has excellent plans for protecting the environment," and "The company has helped the community tidy up the environment."

Compared with employees who were employed for 0 to 10 years, the scores of employees who were employed for 16 years or more was significantly higher for the question "The company endeavors to maximize profits." The employment duration significantly influenced the economic responsibility sub-dimension. In the legal responsibility dimension, employees who were employed for 11 years or more scored significantly higher than all other employees for "The company operates normally and pays taxes according to the provisions of tax law" and "The company competes fairly with its rivals," as well as for the following questions in the environmental responsibility sub-dimension: "The company fulfills its obligation to protect the environment and has complied with regulations related to environmental protection" and "The company has excellent plans for protecting the environment." The scores of employees who were employed for 16 years or more were significantly higher than those who were employed for 10 or fewer years for the ethical responsibility dimension and the following questions: "The company provides an excellent working environment for its employees," "The company complies with legal regulations related to employee recruitment and welfare," "The company has employee code of conduct," "The company encourages its employees to receive further training," and "The company's flexible policies help its employees balance their work and lives." Employees who were employed for 16 years or more also scored significantly higher than those employed for 15 or fewer years on the identifying with organizations dimension and the following questions: "I am willing to participate in corporate social responsibility-related activities organized by the company," "I am willing to take corporate social responsibility," "Fulfilling corporate social responsibility can enhance a corporation's image," and "I am willing to participate in community activities organized by the company." Employees who were employed for 11 to 15 years scored significantly higher than all other employees on the providing support to colleague dimension. In addition, those who were employed for 11 years or more scored significantly higher than other employees on the OCB dimension. 
The scores of employees who graduated from university were significantly higher than those of employees who graduated from junior college for the question "I am willing to participate in activities related to corporate social responsibility organized by the company" in the sub-dimension of identifying with organizations.

The scores of employees in the marketing and management departments were significantly higher than those of employees in other departments regarding the following questions: "The company endeavors to maximize profits," "The company continues to increase effective production and to reduce operation costs," and "The company regularly modifies its business direction and develops sustainable plans according to market demands" in the economic responsibility sub-dimension; "The operation department in the company fully protects intellectual property" and "The company competes fairly with its rivals" in the legal responsibility sub-dimension; "The company fulfills its obligation to protect the environment and has complied with regulations related to environmental protection" and "The company has developed plans to reduce energy and resource consumption" in the environmental responsibility sub-dimension; "The company provides an excellent working environment for its employees," "The company has employee code of conduct," "I am willing to participate in activities related to corporate social responsibility-related organized by the company," and "I am willing to take corporate social responsibility" in the ethical responsibility sub-dimension; and all of the questions in the providing support to colleagues sub-dimension. The scores of employees in the marketing and management departments were also significantly higher than those of employees in other departments regarding the sub-dimensions of economic, legal, environmental, and ethical responsibility, the corporate social responsibility dimension, as well as the identifying with organizations sub-dimension, the providing support to colleague sub-dimension, and the OCB dimension. The scores of employees in the management department were significantly higher than those of employees in other departments for the following questions: "The company has short-term, medium-term, and long-term business strategies and plans" in the economic responsibility sub-dimension; "The company operates normally and pays taxes according to the provisions of tax law" and "the operation and management departments in the company comply with the law" in the legal responsibility sub-dimension; "The company has endeavored to prevent pollution," "The company has excellent plans for protecting the environment," and "The company has helped the community tidy up the environment" in the environmental responsibility sub-dimension; "The company complies with legal regulations related to employee recruitment and welfare," "The company employs people with diverse backgrounds," "The company fairly assesses employees' performance," "Employees provide complete and correct information to all customers or suppliers," "The company's flexible policies help its employees balance their work and lives," and "Fulfilling corporate social responsibility can enhance the company's image" in the ethical responsibility sub-dimension; and "I often actively share my work experience with colleagues" in the providing support to colleagues sub-dimension. In addition, the scores of employees in the marking, management, and research and development departments were significantly higher than those of employees in other departments for the identifying with organizations sub-dimension.

\section{Result}

The present study used listed electronics companies in central Taiwan as an example to investigate the influence of corporate social responsibility on OCB. We draw the following conclusions and discus the theoretical and practical implications of the findings.

\subsection{Results of Hypothetical Tests}

We found that people with diverse backgrounds understood corporate social responsibility to varying degrees. The scores of married employees, women, older employees, senior employees, and supervisors were higher than those of single employees, men, younger employees, junior employees, and non-supervisors, respectively. In addition, the scores of employees in the marketing, management, and research and development departments were higher than those of employees in the production department; therefore, the results support H1. Employees with diverse backgrounds had similar understandings of OCB and corporate social responsibility, which supports H2. Employees who understood that enterprises should fulfill corporate social responsibility presented positive OCB. Therefore, the understanding of corporate social responsibility significantly positively influenced OCB, supporting $\mathrm{H} 3$.

\subsection{Management Implications}

The results of the present study agree with Brammer et al. (2007), according to whom employees engage in positive OCB when they understand that enterprises should take corporate social responsibility. Collier and Esteban (2007) found that the fulfillment of corporate social responsibility positively influenced OCB: if an enterprise fulfilled corporate social responsibility, its employees would identify with the enterprise considerably. 
An enterprise's fulfillment of corporate social responsibility significantly positively influences its employees' OCB. When an enterprise meets social values and requirements, its employees work in a just and sympathetic environment, which enhances their identification with the enterprise. An enterprise's fulfillment of corporate social responsibility can enhance its employees' sense of superiority, make them proud of the enterprise, and endeavor to protect its reputation.

Interviewees doubted that their companies fairly assessed their performance; however, they considered that their companies complied with the law and endeavored to maximize profits.

\section{Conclusion}

Medium or large enterprises, or listed electronics companies that intend to fulfill corporate social responsibility, should invite supervisors, senior employees, or female employees to communicate with those who do not typically participate in decision making or regular meetings (e.g., employees who work on production lines, or those who are not supervisors or do not work in marketing) by holding meetings, providing training, or sending them manuals or letters. This can enhance organizational citizens' identification with their company, motivating them to help their companies fulfill corporate social responsibility and thereby improve corporate image, enhance employee commitment and awareness of organizational citizenship, and create an improved organizational climate. Although employees often express that their organizations should run activities related to corporate social responsibility, they seldom participate in these activities. Therefore, taking on such activities, companies should explain their meanings and goals to encourage organizational citizens to participate in them.

The employees of the company should take the initiative to participate in the corporate social responsibility activities organized by the company, and encourage the surrounding colleagues to participate together to assist the company in fulfilling its obligations in corporate social responsibility, and make the organizational atmosphere more harmonious, and the centripetal force of the employees will be powerful.

\section{References}

Aguinis, H., \& Glavas, A. (2013). Embedded versus peripheral corporate social responsibility: Psychological foundations. Industrial and Organizational Psychology, 6(4), 314-332. https://doi.org/10.1111/iops.12059

Bateman, T. S., \& Organ, D. W. (1983). Job satisfaction and the good soldier: The relationship between affect and employee citizenship. Academy of Management Journal, 26(4), 587-595. https://doi.org/10.5465/255908

Bowen, H. A. (1953). Social Responsibility of the Businessman. New York: Harpers and Brothers.

Brammer, S., Millington, A., \& Rayton, B. (2007). The contribution of corporate social responsibility to organizational commitment. International Journal of Human Resource Management, 18(10), 1701-1719. https://doi.org/10.1080/09585190701570866

Bundy, J., Shropshire, C., \& Buchholtz, A. (2013). Strategic cognition and issue salience: Towards an explanation of firm responsiveness to stakeholder concerns. Academy of Management Review, 38(3), 352-376. https://doi.org/10.5465/amr.2011.0179

Carroll, A. B. (1979). A three-dimensional conceptual model of corporate performance. Academy of Management Review, 4(4), 497-505. https://doi.org/10.2307/257850

Carroll, A. B. (1996). Business and Society: Ethics and stake-holder management (3rd ed.). Ohio: South-Western College Publishing Co.

Carroll, A. B., \& Shabana, K. M. (2010). The business case for corporate social responsibility: A review of concepts, research and practice. International Journal of Management Reviews, 12(1), 85-105. https://doi.org/10.1111/j.1468-2370.2009.00275.x

Collier, J., \& Esteban, R. (2007). Corporate social responsibility and employee commitment. Journal of Business Ethics, 16(1), 19-33. https://doi.org/10.1111/j.1467-8608.2006.00466.x

De Roeck, K., Marique, G., Stinglhamber, F., \& Swaen, V. (2014). Understanding employees' responses to corporate social responsibility: Mediating roles of overall justice and organizational identification. International Journal of Human Resource Management, 25(1), 91-112. https://doi.org/10.1080/09585192.2013.781528

Farh, J. L., Earley, P. C., \& Lin, S. C. (1997). Impetus for action: A cultural analysis of justice and organizational citizenship behavior in Chinese society. Administrative Science Quarterly, 42(1), 421-444. https://doi.org/10.2307/2393733

Farooq, O., Payaud, M., Merunka, D., \& Valette-Florence, P. (2014). The impact of corporate social responsibility 
on organizational commitment: Exploring multiple mediation mechanisms. Journal of Business Ethics, 125(4), 563-580. https://doi.org/10.1007/s10551-013-1928-3

Griffin, J. J. (2000). Corporate social performance: Research directions for the 21 st century. Business \& Society, 39, 479-491.

He, J., Zhang, H., \& Morrison, A. M. (2019). The impacts of corporate social responsibility on organization citizenship behavior and task performance in hospitality: A sequential mediation model. International Journal of Contemporary Hospitality Management, $2582-2598$. https://doi.org/10.1108/IJCHM-05-2018-0378

Hwang, I. S., \& Chi, D. J. (2005). A study on enterprise ethics, social responsibility and corporate philanthropy-taking the hi-tech electronic industry in Taiwan as an example. Fudan Journal of the Humanities and Social Sciences, 1(2), 65-82.

Janney, J. J., \& Gove, S. (2011). Reputation and corporate social responsibility aberrations, trends, and hypocrisy: Reactions to firm choices in the stock option backdating scandal. Journal of Management Studies, 48, 1562-1585. https://doi.org/10.1111/j.1467-6486.2010.00984.x

Jin, K. G., \& Drozdenko, R. (2010). Relationships among perceived organizational core values, corporate social responsibility, ethics, and organizational performance outcomes: An empirical study of information technology professionals. Journal of Business Ethics, 92, 341-359. https://doi.org/10.1007/s10551-009-0158-1

Jones, D. A., Willness, C., \& Madey, S. (2014). Why are job seekers attracted by corporate social performance? Experimental and field tests of three signal-based mechanisms. Academy of Management Journal, 57, 383-404. https://doi.org/10.5465/amj.2011.0848

Kao, C., \& Lin, Y. Z. (2008). Corporate Social Responsibility Handbook. Taipei, Taiwan: Commonwealth Publishing Group.

Katz, D. (1964). The motivational basis of organizational behavior. Behavioral Sciences, 9(1), $131-146$. https://doi.org/10.1002/bs.3830090206

Kim, S., \& Lee, Y. J. (2012). The complex attribution process of CSR motives. Public Relations Review, 38(1), 168-170. https://doi.org/10.1016/j.pubrev.2011.09.024

Konovsky, M. A., \& Pugh, S. D. (1994). Citizenship behavior and social exchange. Academy of Management Journal, 37, 656-669. https://doi.org/10.5465/256704

Kotler, P., \& Lee, N. (2005). Corporate Social Responsibility: Doing the Most Good for Your Company and Your Cause. Hoboken, NJ: John Wiley \& Sons.

Kunda, M. M., Ataman, G., \& Kartaltepe, B. N. (2019). Corporate social responsibility and organizational citizenship behavior: The mediating role of job satisfaction. Journal of Global Responsibility, 10(1), 47-68. https://doi.org/10.1108/JGR-06-2018-0018

Lin, C. C. (2005). A cross-level examination of organizational citizenship behavior: an analysis using Hierarchical Linear Modeling (HLM). Journal of Management, 22(4), 503-524.

Lin, C. C. (2007). A cross-level examination on relationships between impression management motive and organizational citizenship behavior toward supervisors: Moderating roles of social interaction and organizational political climate. Journal of Management, 24(1), 93-111.

Lin, S. C. (1992). The effects of distributive and procedural justice on organizational commitment and organizational citizenship behavior. Academy of Management Review, 13(2), 87-107.

Lins, K. V., Servaes, H., \& Tamayo, A. (2017). Social Capital, Trust, and Firm Performance: The Value of Corporate Social Responsibility during the Financial Crisis. The Journal of Finance, 72(4), 1785-1824. https://doi.org/10.1111/jofi.12505

Louise, T., Jian, H., Vishwanath, V. B., \& Polly, P. (2019). Ethical Leadership and Corporate Social Responsibility in China: A Multilevel Study of Their Effects on Trust and Organizational Citizenship Behavior. Journal of Business Ethics, 158, 427-440. https://doi.org/10.1007/s10551-017-3745-6

Malik, S. Y., Hayat Mughal, Y., Azam, T., Cao, Y., Wan, Z. (2021). Corporate Social Responsibility, Green Human Resources Management, and Sustainable Performance: Is Organizational Citizenship Behavior towards Environment the Missing Link? Sustainability, 13(3), 1044. https://doi.org/10.3390/su13031044 
Mignonac, K., \& Richebé, N. (2013). "No strings attached?”: How attribution of disinterested support affects employee retention. Human Resource Management Journal, 23(1), 72-90. https://doi.org/10.1111/j.1748-8583.2012.00195.x

Mowday, R. T., Porter, L. W., \& Steers, R. M. (1979). The measurement of organizational commitment. Journal of Vocational Behavior, 14, 224-247. https://doi.org/10.1016/0001-8791(79)90072-1

Organ, D. W. (1988). Organizational citizenship behavior: The good solider syndrome. Lexington, MA: Lexington Books.

Organ, D. W. (1990). The motivational basis of organizational citizenship behavior. Research in Organizational Behavior, 12, 43-72. Retrieved from https://www.academia.edu/998116/The_motivational_basis_of_organizational_citizenship_behavior

Organ, D. W., Podsakoff, P. M., \& MacKenzie, S. B. (2006). Organizational citizenship behavior: Its nature, antecedents, and consequences. Thousand Oaks, CA: Sage.

Perez, A., \& del Bosque, I. R. (2013). Measuring CSR image: Three studies to develop and validate a reliable measurement tool. Journal of Business Ethics, 118, 265-286. https://doi.org/10.1007/s10551-012-1588-8

Podsakoff, P., MacKenzie, S., Lee, J., \& Podsakoff, N. (2012). Sources of method bias in social science research and recommendations on how to control it. Annual Review of Psychology, 65, 539-569. https://doi.org/10.1146/annurev-psych-120710-100452

Porter, M. E., \& Kramer, M. R. (2006). Strategy and society: The link between competitive advantage and corporate social responsibility. Harvard Business Review, 84(12), 78-92. https://doi.org/10.1108/sd.2007.05623ead.006

Robinson, S. L., \& Morrison, E. W. (1995). Psychological contracts and OCB: The effect of unfulfilled obligations on civic virtue behavior. Journal of Organizational Behavior, 16, 289-298. https://doi.org/10.1002/job.4030160309

Rupp, D. E., Shao, R., Thornton, M. A., \& Skarlicki, D. P. (2013). Applicants' and Employees' reactions to corporate social responsibility: The moderating effects of first-party justice perceptions and moral identity. Personnel Psychology, 66(4), 895-933. https://doi.org/10.1111/peps.12030

Saeidi, S. P., Sofian, S., Saeidi P., Saeidi, S. P., \& Saaeidi, S. A. (2015). How does corporate social respondibility contribute to firm financial performance? The mediating role of competitive advantage, reputation, and customer satisfaction. Journal of Business Research, 68(2), 341-350. https://doi.org/10.1016/j.jbusres.2014.06.024

Smith, C. A., Organ, D. W., \& Near, J. P. (1983). Organizational citizenship behavior: Its nature and antecedent. Journal of Applied Psychology, 68(4), 653-663. https://doi.org/10.1037/0021-9010.68.4.653

Soliman, S., \& Saad, S. (2021). Impact of Corporate Social Responsibility on Employee Organizational Citizenship Behavior in Egyptian Hotels. Journal of Association of Arab Universities for Tourism and Hospitality, 20(1), 220-235. https://doi.org/10.21608/jaauth.2021.58824.1122

Stites, J. P., \& Michael, J. H. (2011). Organizational commitment in manufacturing employees: Relationships with orporate social performance. Business \& Society, 50, 50-70. https://doi.org/10.1177/0007650310394311

Turker, D. (2009). How corporate social responsibility influences organizational commitment. Journal of Business Ethics, 89(2), 189-204. https://doi.org/10.1007/s10551-008-9993-8

Vlachos, P. A., Panagopoulos, N. G., \& Rapp, A. (2014). Employee judgments of and behaviors towards corporate social responsibility: A multi-study investigation of direct, cascading, and moderating effects. Journal of Organizational Behavior, 35, 990-1017. https://doi.org/10.1002/job.1946

Vogel, D. J. (2005). Is there a market for virtue? The business case for corporate social responsibility. California Management Review, 47(4), 19-45. https://doi.org/10.2307/41166315

Wei, W. C., \& Zhuang, Y. H. (2009). An empirical study of relationship among corporate social responsibility, corporate image, consumer's attitude and behavioral intentions. International Journal of Lisrel, 1(2), 1-21.

Weng, W. H. (1987). An empirical study on the legitimacy of enterprises from a perspective of social responsibility. Unpublished doctoral thesis. National Chengchi University, Taiwan: EMBA Program.

Williams, L. J., \& Anderson, S. E. (1992). An alternative approach to method effects using latent variable models: Applications in organizational behavior research. Paper presented at the Meeting of the Academy of 
Management. Las Vegas, NV: Las Vegas University Press.

Zhao, H., \& Zhou, Q. (2021). Socially responsible human resource management and hotel employee organizational citizenship behavior for the environment: A social cognitive perspective. International Journal of Hospitality Management, 95, 102749. https://doi.org/10.1016/j.ijhm.2020.102749

\section{Copyrights}

Copyright for this article is retained by the author, with first publication rights granted to the journal.

This is an open-access article distributed under the terms and conditions of the Creative Commons Attribution license (http://creativecommons.org/licenses/by/4.0/). 